\title{
DIFFERENTIATION OF PART-TIME JOB AND COMBINATION OF DUTIES FROM OTHER TYPES OF ACTIVITIES IN THE OFFENSE UNDER ARTICLE 1724 OF THE CODE OF UKRAINE ON ADMINISTRATIVE OFFENSES (CUAO)
}

\author{
KORECKA-SZUKIEWICZ Dominika - postgraduate student of Lviv University \\ of Business and Law \\ https://orcid.org/0000-0003-4570-0679 \\ DOI:10.32782/LAW.2020.1.23 \\ UDC 342.95
}

Certain theoretical and practical problematic aspects of administrative responsibility for violation of restrictions on part-time job and combination of duties with other types of activities are considered. Single features of this corruptionrelated offenses have been investigated.

Certain problems, which are still present in the provisions of the administrative legislation in terms of determining the constructive features of the composition of violation of restrictions on part-time job and combination of duties with other activities, have been identified.

Normative legal acts of Ukraine defining the concepts of "part-time job" and "combination of duties", as well as the provisions of the theory of administrative law in determining the content of these concepts have been analyzed.

The main features of part-time job and combination of duties were identified, those features that are common to both concepts, as well as those that differentiate between part-time job and combination of duties have been set.

Key words: administrative liability, administrative liability legislation, corruption offenses, part-time job, combination of duties.

\section{Introduction.}

Implementation of liability for breach of restrictions on part-time job and combination of duties with other activities was a logical step to strengthen state control over the activities of persons authorized to perform the functions of state and local self-government.

Combating corruption is a complex, multidimensional and lengthy process that depends not only on the effective functioning of anticorruption and judicial authorities, but also on the quality of the legislation that, so to speak, sets the rules of the game. In this aspect, the concepts contained in the legal norms should be concise, clear and unambiguous to enable the same law be equally applicable by different subjects of law.

Experience in applying the provisions of Art. $172^{4}$ of the CUAO, as well as theoretical experience in this aspect, testify to the existence of certain problems related to the definition of the terms "part-time job" and "combination of duties", which clearly demonstrates the need for a deeper theoretical search for responsibility for breaking restrictions on part-time job and combination of duties with other activities.

Research of these problems will eliminate the existing theoretical and practical problems, which in turn will lead to a reduction in the number of errors in law enforcement practice, will harmonize the legislation of Ukraine.

In this perspective, it's obvious to analyze of the basic legal acts that determine the content of the declared concepts, the work of theorists in the field of administrative law, as well as other branches of law, which will allow to determine the content of the concepts of "part-time job" and "combination of duties" and to find out their key features.

Based on the above, it is advisable to make a thorough analysis of the provisions of Art. 172 of the CUAO through the prism of the current legislation of Ukraine, as well as through the 
prism of the scientific researches of the doctrine of administrative law.

The declared theme became the subject of scientific research of such scientists as K.L. Buhaichuk, O.I. Bezpalova, N.B. Bolotinoi, V.S. Venediktova, N.V. Verenycha, T.H. Holovan, H.S. Honcharovoi, O.V. Dzhafarova, I.V. Zuba, V.O. Ivantsov, N.M. Korchak, M.V. Molodtsova, P.D. Pylypenka, V.I. Prokopenka, V.H. Rotania, S.O. Shatrava and others.

Considering a lot of theoretical developments on these issues, we should emphasize that some problems in determining a sign of an offense related to violation of restrictions on part-time job and combination of duties with other activities continue to raise a number of objections, also when defining content of the concepts of part-time job and combination of duties, as well as defining their common and distinctive features.

In this aspect, it is obvious that addressing the problems associated with understanding the content of specified concepts is the fundamental task of properly qualifying the action and distinguishing it from related composition of an administrative offense, and so confirms the relevance of the declared theme and the feasibility of further scientific research in this direction.

The purpose of the article is to investigate the provisions of administrative legislation governing liability for violations of restrictions on part-time job and combination of duties with other activities, to determine problems related to the delimitation of these concepts on the basis of an analysis of Ukrainian legislation and theoretical experience.

\section{Research results}

The proper level of counteraction to corruption depends on many factors, including high-quality anti-corruption legislation that correctly defines the content and features of a particular act, as well as does not cause difficulties in the application of these provisions in law enforcement practice. Because any law must be concise, understandable and its provisions should not contradict the provisions of other regulations.

Correlation of two concepts, which are socalled key in determining the content of the ac- tion provided for in Art. $172^{4}$ of the CUAO was caused by scientific interest in view of the declared theme.

It's known that Part 1 of Art. $172^{4}$ of the CUAO provides for liability for violations by a person of the statutory restrictions on part-time job and combination of duties with other types of activity, namely in relation to engaging in other paid activities (except teaching, scientific and creative activity, medical and referee practice, instructional practice in sports) or business activities, as well as violations by a person of statutory restrictions on joining a board, other executive or controlling bodies, or the supervisory board of an enterprise or organization for profit (except when the person performs functions of managing shares (parts, divvy) that belongs to the state or territorial community, and represents the interests of the state or territorial community in the council (the supervisory board) or in the audit committee of the business organization) (Part 2 of this article).

At once two concepts that have some similarity, but they must obviously be different in their content, are used in this article by the legislator. Otherwise, their joint use is unjustified and will directly affect the quality of application of this rule in practice.

N.M. Korchak rightly points out that there are some problems in the part of judicial interpretation of determined categories; those categories are basic in establishing signs of a specific administrative offense related to corruption, in violation of restrictions on part-time job and combination of duties with other types of activities, as well as in deciding on the application of a type of administrative penalty defined in the legislation.

In turn, this adversely affects the correctness of the administrative offense qualification of the relevant types of cases. As well as the lack of generalization of case law experience on these issues and explanations of the Higher Specialized Administrative Court only serves to deepen this problems [1, pp.80-81].

In view of this, attention will be focused on the legislative definitions of "part-time job" and "combination of duties", as well as their theoretical interpretations.

First of all, it should be emphasized that "part-time job" and "combination of duties" as a 


\section{Кримінальне право, кримінальний процес та криміналістика}

concept has been reflected in some way in the legislation of Ukraine. Thus, in a joint decree of the Ministry of Labor of Ukraine, the Ministry of Justice of Ukraine, the Ministry of Finance of Ukraine No. 43 of 28.06.1993, which approved the provision "On working conditions by part-time job for employees of state-owned enterprises, institutions and organizations", it is determined that part-time job is considered as a work made by employee, except their main work, other regular paid work under the terms of the contract of employment at the free time from their main work at the same or another enterprise, institution, organization or citizen (entrepreneur, private person) for by hiring [2].

On the definition of this concept and define it taking into account the provisions of the legislation of Ukraine scientists are generally unanimous.

For example, as T.H. Holovan notes, parttime job is the performance by an employee, in addition to his/her main work, provided at the conclusion of an contract of employment (contract for service), of other work under the terms of the contract(s) of employment at the same or another enterprise, institution, organization or individual, in his/her free from his/ her main job time, and the combination of duties of the professions (positions) - performance by an employee at the same enterprise, institution, organization, in addition to his/her main work, stipulated in a contract of employment, of additional work in another profession (position) within the same working time with surcharge in the amounts stipulated in the collective agreement [3, p.14].

Instead of this, M.E. Pankin offers to understand part-time job as a performance of other regular paid work by an employee on the terms of an contract of employment in free from his/ her main work time [4, p.13-14].

Scientific publications on the subject indicate that the concept of "external part-time job" and "internal part-time job" are also used in practice. If an employee works at two enterprises, one of which is the principal place of work and the other is a part-time job, then that work is considered to be external part-time job. If an employee works at the same enterprise as the principal worker and in his/her free time, performs part-time job, then this work is considered to be internal part-time job [5, p.13].

The legislator has established restrictions for implementation of other paid activities for a certain category of persons. However, the legislator itself provided certain exceptions in this article, in particular, this prohibition does not apply to cases where such persons combine activities with teaching, scientific and creative activity, medical and judicial practice, instructor practice in sports.

Despite this, things are not so clear in this section. As M.I. Khavroniuk points out, teaching, scientific and creative activity, medical practice, instructional and refereeing practice in sports can be types of entrepreneurship . Therefore, if the person concerned engages in them as entrepreneurship (alone or through a certain person, especially relatives) there is a clear violation of the prohibition established by the legislation of Ukraine, he notes [6, p.195].

There is one interesting fact that for other persons not belonging to the category of corruption-related offenders, the list of non-aggregate types of activities is much wider. So, in the aforementioned provision it is defined that part-time job: 1) literary work, including editing, translating, and peer reviewing individual works, paid for by the author's fee; 2) technical, medical, accounting and other expertise with a one-time pay; 3) pedagogical work up to 240 hours per year with an hourly wage; 4) implementation of duties of medical consultants of healthcare institutions up to a maximum of 12 hours per month with a one-time pay; 5) guidance of graduate students in research institutions and higher education institutions of scientists and highly qualified specialists who are not in the staff of these institutions, with their work payment at the rate of 50 hours per year for the guidance of each graduate student; management of the department by highly qualified specialists, including those occupying leading positions in educational institutions and research institutions with payment in the calculation of 100 hours per academic year; 6) consultations by scientific workers of research institutes, teachers of higher educational institutions and institutes of improvement of doctors, by main specialists of health authorities in medical and preventive institutions up to 240 
hours per year with hourly remuneration; 7) work of leading scientific, scientific-pedagogical and practical workers on short-term training of staff on contracts at the enterprises and in the organizations; 8) work without taking a full-time position at the same enterprise, institution, organization, implementation of duties of management in offices, laboratories and departments by teachers of secondary education institution and teachers of professional educational and higher educational institutions, pedagogical work of managers and other employees in educational institutions, management of subject and cycle commissions, guidance of production training and practice of pupils and students, alternation of health workers over a monthly norm of working time, etc., work of teachers of secondary education institution and teachers of professional educational and higher educational institutions, as well as higher educational institutions that are equal to them in remuneration of employees, concertmasters and accompanists of educational institutions for training of workers of arts and music departments (faculties) of other higher educational institutions, in the same educational institution above the established norm of educational load, pedagogical work and management of hobbies groups in the same school, preschool, extracurricular educational institution; 9) transcription of musical notes, which is custom-made for businesses; 10) organization and conducting of excursions on the terms of hourly or parttime remuneration, as well as support of tourist groups in the system of tourist-excursion institutions of trade unions; 11) other work performed when the employee have part-time employment at the main job and accordingly receives a part-time salary if his/her remuneration for basic and other work does not exceed the full salary at the main place of work [2].

In view of the above-mentioned part-time job is characterized by the following features: 1) performance of the employee other work, in addition to his/her main; 2) such work must be performed under the terms of an contract of employment; 3) be on a regular basis; 4) such work must be paid for; 5) to be performed in free from main work time; 6) employee performs other work at the same or another enterprise, institution, organization or citizen (entre- preneur, individual) for hire. Of course, except for the mentioned above cases specified by law.

Similar features are also distinguished by scientists. Thus, in the scientific works to the main features suggest to attribute: part-time job is performed only on the basis of an contract of employment or contract for service; the work of a compatible employee may be performed not only at the place of the main work, but also at the same time at another enterprise, institution, organization or a individual person who uses hired labor; part-time job takes place in free from the main work time. [3, p.15].

According to N.V. Verenych these features include: firstly, part-time job involves performing, in addition to the main work of another, besides, the number of such works is not limited by law; secondly, all part-time job is performed on the basis of an contract of employment or contract for service; thirdly, such contract of employments or contracts for service may be entered into with entities of different forms of ownership [7, p.251-252].

Instead, the others on the basis of a systematic approach and interpretation of legislative acts distinguish the following essential features of the term "part-time job" as a category of exercised labor law: 1) in free from main work time; 2) at one/different enterprise, institution, organization (external/internal part-time job); 3) for payment for actually performed work without restriction; 4) on the terms of the contract(s) of employment [1, p.82].

Instead, the legislative definition of combination of duties is contained in Part 1 of Art. 105 of the Labor Code. In particular, it is noted that there is an extra payment for the combination of duties of the professions (positions) or performance of duties of a temporarily absent employee for employees who works at the same enterprise, institution, organization, in addition to their main work, stipulated in a contract of employment, additional work in another profession (position) or duties of a temporarily absent employee without dismissal from their main work [8].

Given this, it is possible to distinguish the following alignment features: 1) performing an employee of extra work in addition to main work; 2) such additional work should be performed exclusively at the same enterprise, 


\section{Кримінальне право, кримінальний процес та криміналістика}

institution, organization; 3) additional work is carried out solely by another profession (position) or the person performs the duties of a temporarily absent employee without being released from the main work; 4) there is an extra charge for combination of duties professions (positions) or performing the duties of a temporarily absent employee.

According to some scholars, the following characteristics are more meaningful for the combination of duties of the professions (positions): the combination of duties of the professions (positions) occurs only in the presence of agreement of the parties to the contract of employment; an employee at the same time as own duties in own main profession (position) performs duties in another additional profession or in another position; performance of work duties by the employee's main and combinated profession (position) is carried out within the framework of one contract of employment; performance of work in the conditions of combination of duties of the professions (positions) is carried out during the working normal duration day at the expense of labor intensification; performance of basic and combinated work takes place only within one production unit that is at one enterprise, institution, organization or in one individual; for the performance of work duties in an additional profession or position, an employee receives a supplement, the amount of which is established by a collective agreement in accordance with the current legislation [3, p.15].

\section{Conclusions}

As a result, the key differences between part-time job and combination of duties can be determined that, when combinated, additional work is carried out: firstly, at the same enterprise, institution or organization, while in case of part-time job is allowed to work at another enterprise, another institution or organization; secondly, in case of combination of duties, unlike part-time job, the work is performed in another profession (position); thirdly, other work in case of part-time job is paid separately, and in case of combination of duties, only the extra pay to the salary on main place of work is paid for the combination of duties of the professions (positions) or performance of the duties of a temporarily absent employee; fourthly, unlike part-time job, combination of duties is possible only in free from main work time; fifthly, performance of other work must be regular in case of combination of duties.

\section{Reference list:}

1. Korchak N.M. Problems of applying administrative responsibility for violation of restrictions on performance of other paid work or business activity / N.M. Korchak, Y.O. Korchak // Legal Bulletin, 2016, Issue 2 (39). pp. 80-85

[Корчак Н. М. Проблематика застосування адміністративної відповідальності за порушення обмежень щодо заняття іншою оплачуваною роботою або підприємницькою діяльністю / Н. М. Корчак, Я. О. Корчак // Юридичний вісник, 2016. Вип. 2(39). C. $80-85]$

2. On approval of the Regulations on the conditions of part-time job of employees of state-owned enterprises, institutions and organizations: Order of the Ministry of Labor of Ukraine, Ministry of Justice of Ukraine, Ministry of Finance of Ukraine dated June 28, 1993 № 43. [Electronic resource]. Access mode: http://zakon4.rada.gov.ua/laws/show/ z0076-93

[Про затвердження Положення про умови роботи за сумісництвом працівників державних підприємств, установ і організацій: Наказ Міністерства праці України, Міністерства юстиції України, Міністерства фінансів України від 28.06.1993 року № 43. [Електронний ресурс]. Режим доступу: http://zakon4.rada.gov.ua/laws/show/z0076-93]

3. Holovan T.H. Part-time job and combination of duties of the professions (positions) in labor law / T. H. Holovan: Abstract of dissertation ... Candidate of Law in specialty 12.00.05 - Labor Law; social security law // Kharkiv National University of Internal Affairs. Kharkiv, 2007. p.19

[Головань Т. Г. Сумісництво та суміщення професій (посад) в трудовому праві / Т. Г. Головань : Автореф. дис. ... кандидат юридичних наук зі спеціальності 12.00.05 трудове право; право соціального забезпечення // Харківський національний університет внутрішніх справ. Харків, 2007. 19 с.] 


\begin{tabular}{|c|}
\hline 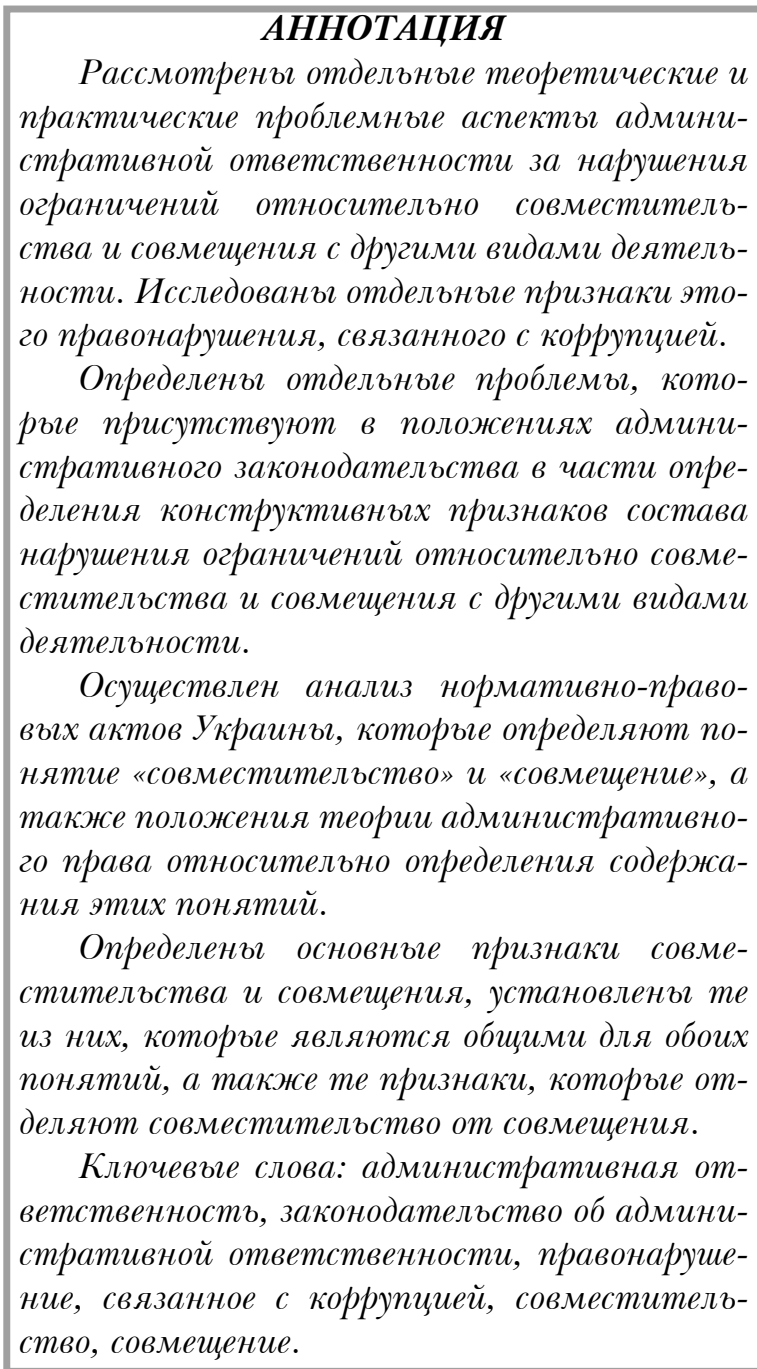 \\
\hline
\end{tabular}

4. Pankin M.E. Part-time job and combination of duties / M.E. Pankin: Legal literature, 1991, p.208

[Панкин М.Е. Совместительство и совмещение / М. Е. Панкин. М. : Юрид. литератуpa, 1991. 208 c.]
5. Buhaichuk K.L. Administrative liability for corruption-related offenses [Text]: practical guide / K.L. Buhaichuk, O.I. Bezpalova, O.V. Dzhafarova, V.O. Ivantsov, S.O. Shatrava, Kharkiv: Kharkiv National University of Internal Affairs, 2016. p.100

[Бугайчук К. А., Адміністративна відповідальність за правопорушення пов'язані із корупцією [Текст] : практич. посіб. / К. А. Бугайчук, О. I. Безпалова, О. В. Джафарова, В. О. Іванцов, С .О. Шатрава. Харків : Харківський національний університет внутрішніх справ. 2016. 100 с.]

6. Scientific and Practical Commentary on the Law of Ukraine "On Prevention of Corruption" / Scientific edition Khavroniuk M.I. K.: Vaite, 2018. p.472

[Науково-практичний коментар до Закону України «Про запобігання корупції» / Наук. ред. Хавронюк М.І. К. : Ваіте, 2018. 472 c.]

7. Verenych N.V. The concept of parttime job and combination of duties under the labor legislation of Ukraine / N.V. Verenych // Bulletin of the Kharkiv National University of Internal Affairs, 2001. № 14. p.251-254

[Веренич Н. В. Поняття сумісництва і суміщення за трудовим законодавством України / Н. В. Веренич // Вісник Харківського національного університету внутрішніх справ, 2001. № 14. С. 251-254]

8. Code of Laws of Labor of Ukraine: Law of Ukraine of December 10, 1971 № 322-VIII. [Electronic resource]. Access mode: https:// zakon.rada.gov.ua/rada/show/322-08

[Кодекс законів про працю України : Закон України від 10.12.1971 № 322-VIII. [Електронний ресурс]. Режим доступу: https://zakon.rada.gov.ua/rada/show/322-08] 